\title{
Efficacy of Newer Insecticides on Yield Attributes of Garden Pea (Pisum sativum ssp. hortense L.)
}

\author{
Alka Sai*, Anand Kumar Singh, B. K. Singh, \\ Ravinsh Kumar Maurya and Pushpendra Singh
}

Department of Horticulture, Institute of Agricultural Sciences, Banaras Hindu University, Varanasi - 221005, Uttar Pradesh, India

*Corresponding author

\section{A B S T R A C T}

\begin{tabular}{|c|}
\hline Keywords \\
\hline $\begin{array}{l}\text { Garden pea, } \\
\text { Insecticides, } \\
\text { Neonicotinoids, } \\
\text { Grains, Pod, weight }\end{array}$ \\
\hline Article Info \\
\hline $\begin{array}{l}\text { Accepted: } \\
10 \text { April } 2020 \\
\text { Available Online: } \\
10 \text { May } 2020\end{array}$ \\
\hline
\end{tabular}

A field study was conducted during Rabi 2016-2017 at the Vegetable Research Farm, Banaras Hindu University, Varanasi to access the response of newer insecticides (Imidacloprid 600 FS and Thiamethoxam $30 \%$ FS) on yield attributes of garden pea. The two insecticides were applied as seed treatment in different doses. The result of bio-efficiency revealed that the seed treatment with $\mathrm{T}_{3}$ gaucho (Imidacloprid 600 FS) @ $2 \mathrm{ml} / \mathrm{kg}$ was found most effective in promoting yield of garden pea. The garden pea plants exhibited maximum value of yield attributes viz., number of pod per plant (12.34), number of grains per pod (8.07), average pod weight $(\mathrm{gm})(10.01 \mathrm{gm})$, pod yield $(\mathrm{q} / \mathrm{ha})(101.56 \mathrm{q} / \mathrm{ha})$, seed yield (kg/ha) $24.54 \mathrm{~kg} / \mathrm{ha}$ ) and seed index (26.53) were recorded highest in seed treatment with Imidacloprid 600 FS @ $2 \mathrm{ml} / \mathrm{kg}$ of seed and at par with seed treatment with Imidacloprid 600 FS @ 1ml/kg of seed. However, all the seed treatments were found promising over untreated control.

\section{Introduction}

Garden Pea (Pisum sativum ssp. hortense L.) is a valuable vegetable as well as pulse crop all over the world and also known as 'Matar'. Garden Pea is a popular leguminous vegetable in India. It is grown in India mainly for green pods and immature seeds, which are consumed as vegetables. The matured seeds are used as pulse, chatpati, etc. Green peas are rich in vitamin and proteins. Mature seed contain $10.9 \mathrm{~g}$ water $22.9 \mathrm{~g}$ protein, $1.4 \mathrm{~g}$ fat, $60.7 \mathrm{~g}$ carbohydrate, $1.4 \mathrm{~g}$ fibre and $2.7 \mathrm{~g}$ ash (Duke and Ayensu, 1985).Garden pea has a great agronomic value.

In crop rotation, it helps improvement of soil fertility and yield of succeeding crops (Rana and Sharma, 1993). Its cultivation maintains soil fertility through biological nitrogen 
fixation in association with symbiotic rhizobium prevalent in its root nodules and thus plays a vital role in fostering sustainable agriculture (Negi et al., 2006). The biological activity and agricultural uses of neonicotinoid insecticides (Imidacloprid and Thiamethoxam) are enormous and due to their unique physicochemical properties, neonicotinoids have been used in a variety of crops in contributing the yield of the crop.

Their selectivity, lower use rate and safety to beneficial insects especially when used as seed dressers make neonicotinoids an ideal component in any integrated pest management (IPM) program resulting in less xenobiotic load in the environment. The seed treatment with Imidacloprid at $12 \mathrm{ml}$ per $\mathrm{kg}$ of seed produced significantly higher seed index i.e., hundred seed weight $4.42 \mathrm{~g}$ (Praveen et al., 2007). Imidacloprid was observed to be the best treatment which recorded highest incremental fruit yield in brinjal (70.01 q/ha) over the untreated check (Ghosal and Chatterjee, 2013).

The present study deals with the efficiency of newer insecticides Imidacloprid 600 FS and Thiamethoxam $30 \%$ FS at different doses in the yield of garden pea.

\section{Materials and Methods}

The studies were conducted at Vegetable Research Farm, Banaras Hindu University, Varanasi, Uttar Pradesh during Rabi 2016 2017. The garden pea cultivar 'Azad Pea 3' were planted at a spacing of $30 \times 10 \mathrm{~cm}$. The experiments were arranged in a completely randomized block design with three replications on seven treatments per replication. Healthy garden pea seeds, at the recommended seed rate, seed dressing formulations of Thiamethoxam $30 \%$ FS @ 1 $\mathrm{g}$ a.i./ $/ \mathrm{kg}(3.3 \mathrm{ml} / \mathrm{kg}$ seed) and $1.2 \mathrm{~g}$ a.i./ $/ \mathrm{kg}$ (4 $\mathrm{ml} / \mathrm{kg} \mathrm{seed}$ ).
Imidacloprid 600 FS@ 0.6 g a.i. g/kg (1 $\mathrm{ml} / \mathrm{kg}$ seed $), 1.2 \mathrm{~g}$ a.i. $/ \mathrm{kg}$ ( $2 \mathrm{ml} / \mathrm{kg}$ seed $), 1.8$ $\mathrm{g}$ a.i. $/ \mathrm{kg}(3 \mathrm{ml} / \mathrm{kg}$ seed) and $3.6 \mathrm{~g}$ a.i./kg $(6$ $\mathrm{ml} / \mathrm{kg}$ seed) were done. One kilogram of the seed of garden pea taken in separate polythene bags and chemicals were added and thoroughly mixed until all the seeds were uniformly coated with the formulations. The seeds thus treated were then allowed to dry in the shade for twenty four hours and sown in respective plots in the field. Plants were under care so that there was no pest infestation or disease infection. The yield attributes of garden pea viz., number of pods per plant, number of grains per pod, average pod weight (g), pod yield (q/ha) seed yield ( $q / h a)$ and seed index.

\section{Experimental protocol}

\section{Number of pods per plant}

Number of pods was recorded in each picking separately in each treatment. After the last harvesting the number of pods from each selected plant was calculated from all picking. The mean value of pods per plant from five selected plants was worked out after summing.

\section{Number of grains per pod}

Number of grains in five pods was evaluated separately. By counting the number of gains in each pod was recorded. The mean value of grain in five pod was work out.

\section{Average pod weight (g)}

Weight of single pod was taken by measuring the weight in electric weighing balance. The weight of five pods from five selected plant was recorded. The mean value from weight of pod in five pods of each selected plant was arrange and workout. 


\section{Pod yield (q/ha)}

Yield of each treatment per plot was recorded from each picking separately. The yield of each treatment and each picking added and as per plot yield calculate the yield in $q / h a$. On the basis of yield of per unit areas $\times 10000$ sqm.

\section{Seed yield (q/ha)}

Seed yield of each plot was recorded separately and from per plot yield was calculated the seed yield in $\mathrm{q} / \mathrm{ha}$.

\section{Seed index}

Weight of 100 seeds was calculated from each treatment per plot using a weighing balance.

\section{Statistical analysis}

The mean values for all the treatment in each replication were subjected to statistical analysis in the computer program SPAR-II developed by IASRI, New Delhi and the results were computed.

\section{Analysis of variance}

The table for analysis of variance (ANOVA) was set as explained by Gomez and Gomez (1984).

\section{Results and Discussion}

\section{Number of pods per plant}

Perusal of data presented in the Table 1 showed significant difference in the number of pods per plant of garden pea with different seed treatments. The number of pod per plant was recorded highest in seed treatment with $\mathrm{T}_{3}$ gaucho (Imidacloprid $600 \mathrm{FS}$ ) @ $2 \mathrm{ml} / \mathrm{kg}$ seed (12.34) which was statistically at par with treatment $T_{2}$ gaucho (Imidacloprid 600
FS)@ $1 \mathrm{ml} / \mathrm{kg}$ seed (12.12).However, all the seed treatments were superior over untreated control $\mathrm{T}_{1}$ which recorded minimum number of pods per plant (10.10).

\section{Number of grains per pod}

The findings presented in Table 1 showed the number of grains per pod of garden pea was highest in seed treatment with $\mathrm{T}_{3}$ gaucho (Imidacloprid 600 FS) @ 2 ml/kg seed (8.07) which was statistically at par with seed treatment with $\mathrm{T}_{2}$ gaucho (Imidacloprid 600 FS) @ $1 \mathrm{ml} / \mathrm{kg}$ seed (7.87). However, all the treatments were superior over untreated control $\mathrm{T}_{1}$ which recorded minimum number of grains per pod.

\section{Average pod weight (g)}

The average pod weight in different treatment ranged from 9.14 to 10.01 were presented in Table 1 The average pod weight was highest in seed treatment with $\mathrm{T}_{3}$ gaucho (Imidacloprid 600 FS) @ 2 ml $/ \mathrm{kg}$ seed (10.01g) followed by treatment $\mathrm{T}_{2}$ gaucho (Imidacloprid 600 FS) @ 1 ml/kg seed (9.50 g). These treatments were found superior over untreated control $\mathrm{T}_{1}$ which recorded lowest average pod weight $(\mathrm{g})(9.41 \mathrm{~g})$.

\section{Pod yield (q/ha)}

Pod yield ( $\mathrm{q} / \mathrm{ha}$ ) of garden pea presented in the Table 2. The pod yield ( $\mathrm{q} / \mathrm{ha}$ ) of different treatment are ranged between 101.56 to 82.64 $\mathrm{q} / \mathrm{ha}$. The pod yield $(\mathrm{q} / \mathrm{ha})$ in seed treatment with $\mathrm{T}_{3}$ gaucho (Imidacloprid 600 FS) @ $2 \mathrm{ml} / \mathrm{kg}$ seed recorded highest (101.50 q/ha) followed by treatment $\mathrm{T}_{2}$ gaucho (Imidacloprid 600 FS) @ 1ml/kg seed (95.92 q/ha), $\mathrm{T}_{4}$ gaucho (Imidacloprid 600 FS) @ 3 $\mathrm{ml} / \mathrm{kg}$ seed $(94.38 \mathrm{q} / \mathrm{ha})$. The pod yield of all the seed treatments were found to be superior over the untreated control $\mathrm{T}_{1}$ which recorded lowest pod yield (q/ha) (82.64 q/ha). 


\section{Seed yield (q/ha)}

The finding of the present experiment presented in the Table 2 showed the seed yield ( $q /$ ha) of garden pea from different seed treatments. The seed yield $(\mathrm{q} / \mathrm{ha})$ in seed treatment with $\mathrm{T}_{3}$ gaucho (Imidacloprid 600 FS) @ 2ml $/ \mathrm{kg}$ seed was found to be highest (24.54 q/ha) which was statistically at par with treatment $\mathrm{T}_{2}$ gaucho (Imidacloprid 600 FS) @ $1 \mathrm{ml} / \mathrm{kg}$ seed (23.79 q/ha). However, all the treatments were superior over untreated control $T_{1}$ which recorded lowest seed yield (q/ha) (17.65 q/ha).

\section{Seed Index (100 seed weight)}

The findings of the present investigation presented in Table 2, showed the seed index (100 seed weight) of garden pea from different seed treatments. The seed index recorded highest in seed treatment $\mathrm{T}_{3}$ gaucho (Imidacloprid $600 \mathrm{FS}$ ) @ $2 \mathrm{ml} / \mathrm{kg}$ seed (26.53 g), which was statistically at par with treatment $\mathrm{T}_{2}$ gaucho (Imidacloprid 600 FS) @ $1 \mathrm{ml} / \mathrm{kg}$ seed $(26.25 \mathrm{~g})$.

However, the seed index of all the treatments were recorded superior than the untreated control $\mathrm{T}_{1}$ which recorded the lowest seed index (25.07).

\section{Discussion}

\section{Number of pods per plant}

It is declared from the finding of the present investigation that the seed treatments were significantly superior over untreated control $\mathrm{T}_{1}$. The treatment $\mathrm{T}_{3}$ gaucho (Imidacloprid 600 FS) @ 2ml/kg seed recorded maximum number of pods per plant (12.34).The next advanced seed treatments was $\mathrm{T}_{2}$ gaucho (Imidaclopriod 600 FS) @ $1 \mathrm{ml} / \mathrm{kg}$ seed (12.12). This finding is in conformity with Bhargava and Bhatnagar (2001) that the number of pod per plant and yield were superior in plots with imidacloprid 600 FS and $70 \mathrm{WS}$ than the untreated check in okra.

\section{Number of grains per pod}

Different seed treatment exhibited significant differences in number of grains per pod. It is conceded from the data that the seed treatments were significantly superior over untreated control $\mathrm{T}_{1}$. The treatment $\mathrm{T}_{3}$ gaucho Imidacloprid 600 FS) @ 2ml/kg seed treatment recorded maximum number of grains per pod (8.07). The next refined seed treatment was $\mathrm{T}_{2}$ gaucho (Imidaclopriod 600 FS) @ $1 \mathrm{ml} / \mathrm{kg}$ seed (7.87). This Finding are in agreement with the Manjunath et al., (2009), who observed that chilli seed treated with Imidacloprid along with zinc sulphate and captan was proved to give higher number of grain or seed per fruit than the other treatment which was 171.34. Praveen et al., (2007), who reported number of seed or grain per fruit is recorded highest 40.53 in seed treated with Imidacloprid and next best result found in seed treated Thiamethoxam which was recorded 40.03 as compared to the untreated control which was 36.39 .

\section{Average pod weight (g)}

Average pod per weight (g) indicated significant effect in different seed treatments. It is approved from the present experiment that the seed treatment with $\mathrm{T}_{3}$ gaucho (Imidacloprid 600 FS) @ 2ml/kg seed recorded highest average weight of pod per plant $(10.01 \mathrm{~g})$. The next leading treatment was $\mathrm{T}_{2}$ gaucho (Imidacloprid 600 FS) @ 1 $\mathrm{ml} / \mathrm{kg}$ seed $(9.50 \mathrm{~g})$. This finding is in conformity with Kumar (1998) reported that cotton yield was found to be increased with Imidacloprid $70 \mathrm{WS}$ at $7 \mathrm{~g} / \mathrm{kg}$ seed and increased fruit weight by 42 to 48 per cent, thus indicating the significant effect of insecticide treatments on fruit weight. 


\section{Pod yield (q/ha)}

Different treatment showed significant variation with regards to pod yield (q/ha).It is conceded from the present study that the seed treatments were significantly superior over untreated control $T_{1}$. The seed treatment $T_{3}$ gaucho (Imidacloprid 600 FS) @ 2ml/kg seed recorded highest pod yield $(\mathrm{q} / \mathrm{h})(101.56$ $\mathrm{q} / \mathrm{ha})$. The next best seed treatment was $\mathrm{T}_{2}$ gaucho (Imidacloprid $600 \mathrm{FS}$ ) @ $1 \mathrm{ml} / \mathrm{kg}$ seed $(95.92 \mathrm{q} / \mathrm{ha})$. The above finding is in line with Anitha and Nandihalli (2009) observed that the treatment with Imidacloprid $200 \mathrm{SL}$ recorded highest fruit yield $(47.71 \mathrm{q} / \mathrm{ha})$ followed by Imidacloprid 70 WS (44.43 q/ha) and Thiamethoxam 70WS (44.10 q/ha). Sreelatha and Diwakar (1997), also reported that seed treated with Imidacloprid gave increased yield over control. Faqir and Gul (1998) also reported that the yield was highest in Imidacloprid treated plot.

\section{Seed yield (q/ ha)}

It is indicated from the present experiment that the seed treatments were significantly superior over untreated control $\mathrm{T}_{1}$. The treatment $\mathrm{T}_{3}$ gaucho (Imidacloprid600 FS) @ $2 \mathrm{ml} / \mathrm{kg}$ seed recorded highest seed yield $(\mathrm{q} / \mathrm{h})$ (24.54 q/ha).Kencharaddi and Balikai (2011), reported that maximum yield was realized from Imidacloprid 600 FS @ 10 ml/kg seeds $(13.62 \mathrm{q} / \mathrm{ha})$ and was significantly superior over all the treatments.

Table.1 Effect of seed treatment with Thiamethoxam and Imidacloprid on number of pods per plant, number of grains per pod, average pod weight $(\mathrm{g})$

\begin{tabular}{|c|c|c|c|c|c|}
\hline Treatment & $\begin{array}{l}\text { Dosage/h } \\
\text { a a.i.(g) }\end{array}$ & $\begin{array}{l}\text { Formula } \\
\text { tions }(\mathrm{ml} \\
\text { or } \mathbf{g})\end{array}$ & $\begin{array}{ll}\begin{array}{l}\text { Number } \\
\text { pods of } \\
\text { plant, }\end{array} & \text { per }\end{array}$ & $\begin{array}{l}\begin{array}{l}\text { Number of } \\
\text { grains per } \\
\text { pod }\end{array} \\
\end{array}$ & $\begin{array}{l}\text { Average pod } \\
\text { weight }(\mathrm{g})\end{array}$ \\
\hline$T_{1}$ No spray & - & - & 10.10 & 6.40 & 9.14 \\
\hline $\begin{array}{l}T_{2} \text { Gaucho } \\
\text { (Imidacloprid } 600 \mathrm{FS} \text { ) }\end{array}$ & 0.6 & 1 & 12.12 & 7.87 & 9.50 \\
\hline $\begin{array}{l}T_{3} \text { Gaucho } \\
\text { (Imidacloprid } 600 \text { FS) }\end{array}$ & 1.2 & 2 & 12.34 & 8.07 & 10.01 \\
\hline $\begin{array}{l}\mathrm{T}_{4} \text { Gaucho } \\
\text { (Imidacloprid } 600 \mathrm{FS} \text { ) }\end{array}$ & 1.8 & 3 & 11.73 & 7.43 & 9.40 \\
\hline $\begin{array}{l}T_{5} \text { Gaucho } \\
\text { (Imidacloprid } 600 \text { FS) }\end{array}$ & 2.4 & 4 & 11.47 & 6.90 & 9.30 \\
\hline $\begin{array}{l}\text { T }_{6} \text { Thiamethoxam 30\% } \\
\text { FS }\end{array}$ & 1 & 3.3 & 11.39 & 6.87 & 9.24 \\
\hline $\begin{array}{l}T_{7} \text { Gaucho } \\
\text { (Imidacloprid } 600 \text { FS) }\end{array}$ & 6 & 6 & 10.40 & 6.53 & 9.18 \\
\hline CD 5\% & & & 0.30 & 0.66 & 0.18 \\
\hline
\end{tabular}


Table.2 Effect of seed treatment with Thiamethoxam and Imidacloprid on pod yield (q/ha) seed yield (kg/ha), seed index

\begin{tabular}{|l|c|c|c|c|c|}
\hline Treatment & $\begin{array}{c}\text { Dosage/ } \\
\text { ha a.i.(g) }\end{array}$ & $\begin{array}{c}\text { Formula } \\
\text { tions (ml } \\
\text { or gm) }\end{array}$ & $\begin{array}{c}\text { Pod yield } \\
(\mathbf{q} / \mathbf{h a})\end{array}$ & $\begin{array}{c}\text { Seed yield } \\
(\mathbf{q} / \mathbf{h a})\end{array}$ & $\begin{array}{c}\text { Seed } \\
\text { Index }\end{array}$ \\
\hline $\mathbf{T}_{\mathbf{1}}$ No spray & - & - & 82.64 & 17.65 & 25.07 \\
\hline $\begin{array}{l}\mathbf{T}_{\mathbf{2}} \text { Gaucho (Imidacloprid } \\
\text { 600 FS) }\end{array}$ & 0.6 & 1 & 95.92 & 23.75 & 26.25 \\
\hline $\begin{array}{l}\mathbf{T}_{\mathbf{3}} \text { Gaucho (Imidacloprid } \\
\text { 600 FS) }\end{array}$ & 1.2 & 2 & 101.56 & 24.54 & 26.53 \\
\hline $\begin{array}{l}\mathbf{T}_{\mathbf{4}} \text { Gaucho (Imidacloprid } \\
\text { 600 FS) }\end{array}$ & 1.8 & 3 & 94.38 & 23.01 & 26.12 \\
\hline $\begin{array}{l}\mathbf{T}_{\mathbf{5}} \text { Gaucho (Imidacloprid } \\
\text { 600 FS) }\end{array}$ & 2.4 & 4 & 90.12 & 21.43 & 26.11 \\
\hline $\begin{array}{l}\mathbf{T}_{\mathbf{6}} \text { Thiamethoxam 30\% } \\
\text { FS }\end{array}$ & 1 & 3.3 & 87.72 & 21.42 & 25.74 \\
\hline $\begin{array}{l}\mathbf{T}_{\mathbf{7}} \text { Gaucho (Imidacloprid } \\
\text { 600 FS) }\end{array}$ & 6 & 6 & 86.98 & 21.31 & 25.12 \\
\hline CD 5\% & & & 2.93 & 2.55 & 0.97 \\
\hline
\end{tabular}

\section{Seed index}

It is approved from the findings of the present study that the seed treatments were significantly superior over untreated control $\mathrm{T}_{1}$. The seed treatment $\mathrm{T}_{3}$ gaucho (Imidacloprid $600 \quad$ FS) @ $2 \mathrm{ml} / \mathrm{kg}$ seed recorded highest seed index (26.53). The next promising seed treatment was $\mathrm{T}_{2}$ gaucho (Imidacloprid 600 FS) @ 1 ml $/ \mathrm{kg}$ seed (26.25). Praveen et al., (2007), who reported that seed index of okra differed significantly due to seed treatment the seed treatment with Imidacloprid at $12 \mathrm{ml}$ per $\mathrm{kg}$ of seed produced significantly higher seed index i.e., hundred seed weight (4.42 g).

\section{References}

Anitha, K. R. and Nandihalli, B. S. (2009). Bio-efficacy of newer insecticides against leafhopper and aphid in okra. Karnataka Journal Agriculture Science, 22(3): 714-715.
Bhargava, K. K. and Bhatnagar, A. (2001). Bioefficacy of Imidacloprid as a seed dresser against sucking pests of okra. Pest Management Economical Zoology, 9(1): 31-34.

Duke, J. A. and Ayensu, E.S. (1985). Medicinal plants of china. Reference publication. Inc. 1985. ISBN 0-917256, 20:4.

Faqir, G. and Gul, F. (1998). Evaluation of different insecticides and cultivars against jassid in okra. Sarhad Journal Agriculture, 14(4): 351-354.

Ghosal, A. and Chatterjee, M. L. (2013). Bioefficacy of imidacloprid 17.8 SL against whitefly,(Bemisia tabaci Gennadius) in brinjal. Journal Plant Protection Science, 5(1): 37-41.

Gomez, K. A. and Gomez, A.A. (1984). Statistical procedure for Agricultural Research. Second Edition. A Wiley Inter Science Publications John Wiley and Sons, New York. Chichester. Torento. Singapore. p.680. 
Kencharaddi, A. V. and Balikai, R. A. (2011). Effect of Imidacloprid and Thiamethoxam treated stored seeds on sucking pests in sunflower. Annals Plant Protection Science, 20:107-113.

Kumar, K. (1998). Studies on bio-efficacy and determination of residues of imidacloprid applied against sucking pests on cotton. Ph. D Thesis, Tamil Nadu Agricultural University, Coimbatore : 160

Manjunath, S. N., Deshpande, V. K., Sridevi, D. S. Uppar, O., Babalad, H. B. and Rao, M. S. L. (2009). Influence of seed pelleting on crop growth, seed yield and quality of paprika chilli (Capsicum annuum L.). Karnataka Journal Agriculture Science, 22(4): 762-764.

Negi, S., Sing, R.V. and Dwivedi, O.K. (2006). Effect of Bio-fertilizers, nutrient sources and lime on growth and yield of garden pea, Legume research, 29(4): 282-285.

Praveen, K. S., Ashok, S. S., Patil, R. K., Dharmatti, P. R. and Kurdikeri, M. B. (2007). Influence of sees treatment and foliar spray with insecticides and neem products on growth and seed yield in okra (Abelomoschus esculentus [L] Moench) Karnataka Journal Agricultural Science, 20(2): 388-390.

Rana, K. S. and Sharma, S. K. 1993. Effect of Rabi legumes on nitrogen economy and productivity of direct seeded upland rice. Crop Research Hisar, 6(1): 165167.

Sreelatha and Divakar, B. J. (1997). Impact of imidacloprid seed treatment on insect pest incidence in okra. Indian Journal Plant Protection, 25: 52-55.

\section{How to cite this article:}

Alka Sai, Anand Kumar Singh, B. K. Singh, Ravinsh Kumar Maurya and Pushpendra Singh. 2020. Efficacy of Newer Insecticides on Yield Attributes of Garden Pea (Pisum sativum ssp. hortense L.). Int.J.Curr.Microbiol.App.Sci. 9(05): 1365-1371. doi: https://doi.org/10.20546/ijcmas.2020.905.154 